\title{
The inhibitory effect of Mesembryanthemum edule (L.) bolus essential oil on some pathogenic fungal isolates
}

\author{
Beauty E Omoruyi ${ }^{1}$, Anthony J Afolayan ${ }^{2}$ and Graeme Bradley ${ }^{\text {1* }}$
}

\begin{abstract}
Background: Mesembryanthemum edule is a medicinal plant which has been indicated by Xhosa traditional healers in the treatment HIV associated diseases such as tuberculosis, dysentery, diabetic mellitus, laryngitis, mouth infections, ringworm eczema and vaginal infections. The investigation of the essential oil of this plant could help to verify the rationale behind the use of the plant as a cure for these illnesses.

Methods: The essential oil from M. edule was analysed by GC/MS. Concentration ranging from $0.005-5 \mathrm{mg} / \mathrm{ml}$ of the hydro-distilled essential oil was tested against some fungal strains, using micro-dilution method. The plant minimum inhibitory activity on the fungal strains was determined.

Result: GC/MS analysis of the essential oil resulted in the identification of 28 compounds representing 99.99\% of the total essential oil. A total amount of 10.6 and $36.61 \%$ constituents were obtained as monoterpenes and oxygenated monoterpenes. The amount of sesquiterpene hydrocarbons (3.58\%) was low compared to the oxygenated sesquiterpenes with pick area of 9.28\%. Total oil content of diterpenes and oxygenated diterpenes detected from the essential oil were $1.43 \%$ and $19.24 \%$. The fatty acids and their methyl esters content present in the essential oil extract were found to be $19.25 \%$. Antifungal activity of the essential oil extract tested against the pathogenic fungal, inhibited C. albican, C. krusei, C. rugosa, C. glabrata and C. neoformans with MICs range of 0.02-0.31 mg/ml. the activity of the essential oil was found competing with nystatin and amphotericin B used as control.

Conclusion: Having accounted the profile chemical constituent found in M. edule oil and its important antifungal properties, we consider that its essential oil might be useful in pharmaceutical and food industry as natural antibiotic and food preservative.
\end{abstract}

Keywords: Mesembryanthemum edule, Essential oil, GC/MS, Antifungal activity, Opportunistic fungi

\section{Background}

The global epidemics of HIV/AIDS appear to have stabilized in most regions. However, Sub-Saharan Africa remains heavily affected region according to the report of UNAIDS [1]. Among the Sub-Saharan Africa countries, South Africa happened to be the largest burden of HIV/ AIDS worldwide with an estimate of 5,38 million out of 50.6 million indigenes in 2011 [2]. Majority of people living with HIV/AIDS are vulnerable to developing fungal illness because of their suppressed immune systems

\footnotetext{
* Correspondence: gbradley@ufh.ac.za

'Department of Biochemistry and Microbiology, University of Fort Hare, Private Bag X1314, Alice 5700, South Africa

Full list of author information is available at the end of the article
}

$[3,4]$. Fungal infections remain a significant cause of gastrointestinal disease, a consequence of HIV/AIDS contaminants especially in immunocompromised individuals $[3,4]$. The incidence of re-occurring fungal associated HIV/AIDS has increased dramatically. Candida albicans is one of the major causes of mucosal and bloodstream infections with over $85 \%$ to $95 \%$ cases reported if not treated [4]. Cryptococcus neoformans, a facultative organism that is very unique in attacking the lymphocytic cells, thereby creating a major gate way to HIV target. Meningitis, including lung infections are the common diseases related to C. neoformans [5].

Candida glabrata currently ranks the second or third causative agent of oral, vaginal, or urinary infections, 
which is often known as nosocomial disease. Its resistant mortality rates in compromised patients are very difficult to treat, especially with fluconazole drug [6]. Susceptibility of population with suppressed immunological defences against Candida rugosa infection in HIV/AIDS has emerged in spreading bovine mastitis in trauma patients $[7,8]$. Overall, Candida krusei ranked the fifth most common species that tends to be relatively seen in immunocompromised patients [8].

Over the years, the prevalence of fungal infection and its resistance to antibiotics drugs has brought to knowledge the importance to search for alternative treatments against infections [9]. It is noteworthy that researchers have directed their attention towards medicinal plants to develop better drugs against fungal infections. Traditional medicines have played an important role in health services around the globe, especially in South Africa due to wide arrays of phytochemicals with therapeutic properties [10]. Naturally, plants possesses free radical scavenging molecules, such as vitamins, terpenoids, phenolic acids, tannins, flavonoids, alkaloids, and other metabolites, which are rich in antioxidant with antimicrobial properties $[11,12]$. The ingestion of these natural antioxidants has shown to enhance the immune defence, reduce risks of cancer, cardiovascular disease, diabetes, and other diseases associated with ageing $[12,13]$. Owing to this fact, majority of South African population relies heavily on the use of plants and plant extracts for their well beings. Hence, much attention has been drawn to plantderived fungicides in recent years for the replacement of modern drugs [14]. Essential oil and their volatile constituents derived from medicinal plants have been reported to possess potent antifungal activities [15]. Majority of individuals who use essential oils from plant is less likely to contract infections disease [16]. Moreover, oils users who eventually contract an infectious disease trend to recover faster than those using antibiotics [17].

In South Africa, essential oils are usually used to preserve food against the growth of organisms. Thus many of these essential oils from medicinal plants are cheaply distributed and sold in the local market centers due to increased demands [2]. The high reliance on medicinal plants for health purposes necessitates the scientific validation of their therapeutic value and safety.

Mesembryanthemum edule (L.) bolus is an edible growing ground-cover plant commonly found in the costal districts of Eastern Cape of South Africa. The Xhosaspeaking people in this province usually administered alcohol, aqueous and essential oil extracts for the management of diseases common with HIV/AIDS infection [18]. Based on the ethnomedical information on this plant, the crude essential oil extract was screened for activity against Candida albican, C. rogusa, C. krusei, C. glabrata and C. neoformans. The activities of $M$. edule on mycobacteria causing tuberculosis (TB) have been described [14], but reports on the biological effect of its essential oil on pathogenic fungal isolated from HIV/ AIDS patients are limited. The aim of this research is to evaluate the inhibitory potential of $M$. edule essential oil against fungal isolated from HIV/AIDS patients. This study may justify its authentication to be used as complementary and alternative medicines.

\section{Methods}

\section{Plant material}

After obtaining the human ethics certificate (BRA0S1OMUO1) approved by the University of Fort Hare's research ethics committee, the survey of this medicinal plant was carried out in June 2012, fresh leaves of M. edule were supplied by herbalist from Nkonkobe Municipality. The taxonomical identity of the plant was confirmed by a botanist Prof. DS Grierson and a voucher specimen was kept in the Griffin Herbarium of the Botany Department, University of Fort Hare as (Omo 2011/1-Omo 2011/19) [18].

\section{Essential oil}

Volatile oil from the fresh leaves $(500 \mathrm{~g})$ was extracted for $3 \mathrm{~h}$ using a hydro-distiller (Clevenger's-type apparatus) in a 5-L round bottom flask fitted in a condenser. This process of extraction was repeated by another $500 \mathrm{~g}$ of the fresh leaves.

\section{Gas chromatography-mass spectroscopy analysis}

The essential oil extract was subjected to GC-MS analysis for identification of components in the department of Botany, University of Forth Hare. This was carried out using GC-MS (HP 6890) with a mass selective detector (HP5973). Identification of the components of essential oils was accomplished by comparison with the standards available in the database. The quantity of compounds was calculated by integrating the peak areas of spectrograms. A needle with the sample material (essential oils tested) was inserted directly into the inlet of a Hewlett Packard (HP 6890, USA) Gas Chromatograph. The temperature of the injection port was maintained at $220^{\circ} \mathrm{C}$ while the pressure at the inlet was maintained at 3.96 psi. A HP-5 MS (cross-linked 5\% Phenyl Methyl Siloxane $)$ column $(30 \mathrm{~m} \times 0.25 \mathrm{~mm} \times 0.25 \mu \mathrm{m}$ film thickness) was temperature- programmed from 60 to $150^{\circ} \mathrm{C}$ at $3^{\circ} \mathrm{C}$ min- 1 after a 3 min delay. Helium was used as a carrier gas at $0.7 \mathrm{ml} \mathrm{min-1.} \mathrm{Mass} \mathrm{spectra} \mathrm{were} \mathrm{recorded} \mathrm{by} \mathrm{a}$ 5973 series Mass Selective Detector (MSD) [19].

\section{Calculation of oil yield}

Prior to the final extraction and obtaining the oil, a clean bottle of known mass was made available. At the end of extraction process, the essential oil obtained was carefully transferred into the bottle and the final mass noted. 
The yield was obtained as follows: Mass of plant material distilled $(\mathrm{g})=\mathrm{X}$; Mass of empty bottle $(\mathrm{g})=\mathrm{A}$; Mass of bottle + oil extracted $(\mathrm{g})=\mathrm{B}$; Mass of oil $(\mathrm{g})=(\mathrm{B}-\mathrm{A})$; Percentage $(\%)$ yield $=[(\mathrm{B}-\mathrm{A}) \div \mathrm{X}] 100$ (Table 1$)$. The essential oil was diluted in methanol $(20 \% \mathrm{v} / \mathrm{v})$ and a working concentration ranging between $0.005-5-\mathrm{mg} / \mathrm{ml}$ was used for the determination of Minimum Inhibitory Concentration (MIC).

\section{Microorganisms and growth media}

The fungi used in this study were chosen primarily on the basis of their importance as common pathogens of human infected with HIV/AIDS. Strains from the American type culture collection (ATCC) were used, including C. albicans ATCC 2091, C. krusei ATCC 204305, C. glabrata ATCC 2001, C. rugosa ATCC 10571 and Cryptococcus neoformans ATCC 66031. Both Sabouraud dextrose agar (SDA) and Sabouraud dextrose broth (SDB) were prepared according to the manufacturer's instructions. Each fungus was grown for 48 hour at $28^{\circ} \mathrm{C}$ in Sabouraud Dextrose Agar (Merck) plates. Scrape cell mass were transferred from each solid culture to $3 \mathrm{ml}$ saline solution and then adjusted to $0.5 \mathrm{Mc}$ Farland standard, which was confirmed by spectrophotometric reading at $580 \mathrm{~nm}$ [20]. Cell suspensions were finally diluted to $10^{4} \mathrm{CFU} / \mathrm{ml}$ for the use in the assays.

\section{Minimum Inhibitory Concentration (MIC)}

The micro-dilution method using Sabouraud dextrose broth was employed to determine the minimum inhibitory concentration (MIC) of the plant extracts using 96 well microtitre plates. Firstly, an initially, $120 \mu \mathrm{l}$ of sterile distilled water was added into each well of the first (A) and last $(\mathrm{H})$ rows and also into all the wells of the last column (12). Secondly, $120 \mu \mathrm{l}$ of SDB was added into each well of the second row (B) and $150 \mu \mathrm{l}$ of same SDB was added into the remaining wells of the first column and then a $100 \mu \mathrm{l}$ into the rest of the wells from the second column rightward. Fifty microlitre of the essential oil was then added into the third well of the first column, while $50 \mu \mathrm{l}$ of the positive and negative control were separately added into the remaining wells of the first column. Following two-fold serial dilution method, each contents from the first column (starting from the third row) was mixed by transferring $100 \mu \mathrm{l}$ into the second well of the same row and the procedure was repeated

Table 1 Percentage yield essential oil from M. edule leaves

\begin{tabular}{ll}
\hline Item & Essential oil of leaf \\
\hline Percentage yield & $4.21 \%$ \\
Colour & A very pale yellow \\
Solubility in methanol 20\% & 1 in $1 \mathrm{~N}$ \\
\hline
\end{tabular}

up to the 11th well of the same row and the last $100 \mu \mathrm{l}$ from the 11th well was discarded. Hence various concentrations of the diluted essential oil ranging from $5 \mathrm{mg} / \mathrm{ml}$ to $0.005 \mathrm{mg} / \mathrm{ml}$ were prepared in the wells, following the two-fold dilution method. Thereafter, $20 \mu \mathrm{l}$ of $0.5 \mathrm{Mc}-$ Farland fungal suspensions was inoculated into the wells except those which contained sterile distilled water. Each treatment was performed in triplicates. The growth of the fungi was measured by determining the absorbance at $620 \mathrm{~nm}$ with a microtitre plate reader before and after incubation. Plates were incubated at $37^{\circ} \mathrm{C}$ for 24 hours. The lowest concentration which inhibited the growth of the fungi was considered as the minimum inhibitory concentration (MIC) of each extracts.

\section{Statistical analysis}

The antifungal experiments were made in triplicates and the data is reported as mean \pm SD for $(n=1 \times 3)$. Analysis of variance was performed by one way ANOVA using software statistical 5.5 (Stat Soft Inc, Tulsa, Ok). A probability value at $\mathrm{P}<0.05$ was considered statistically significant.

\section{Results and discussion}

Percentage chemical compounds of the essential oil Hydro-distilled essential oil from fresh $M$. edule leaves analyzed by GC-MS resulted in the identification of 28 compounds representing $99.99 \%$ of the total essential oil. The essential oil was pale yellowish liquid with a fineagreeable characteristic aroma. The major compounds of the essential oil found based on their mass spectra peaks (Figure 1) were the Tetra-decamethylcyclo-heptasiloxane with area peak of $23.81 \%$, followed by Tetra-cosamethylcyclododecasiloxanes (22.51\%), Octadecane (2.56\%), Nephthalene (3.93\%) and Eicosane (4.0\%), Table 2.

The use of some of these chemical compounds has been well studied. Compounds such as Tetra-cosamethylcyclododecasiloxanes and Tetra-decamethylcyclo-heptasiloxane that ends with 'siloxanes' belongs to the wider class of organosilicon [21]. These compounds are made up of both organic and inorganic chemical compounds comprised of silicon, oxygen, carbon and hydrogen [22]. Siloxanes are commonly used in the cosmetic industries to produce deodorants, sunblocks, hairsprays and skincare [21]. In addition, siloxanes are an important product in the cook ware industry and kitchen utensils [21]. They are also used as effective industrial cleaning agents and in dry cleaning industries. In terms of properties, siloxanes are a good source of electric insulation, low chemical reactivity, low toxicity, high gas permeability, excellent resistance to oxygen, zone and UV light. Naphthalene is another chemical compounds derived from crude oil. It is a bicyclic aromatic hydrocarbon that is use as insecticide and as a repellent [23]. 


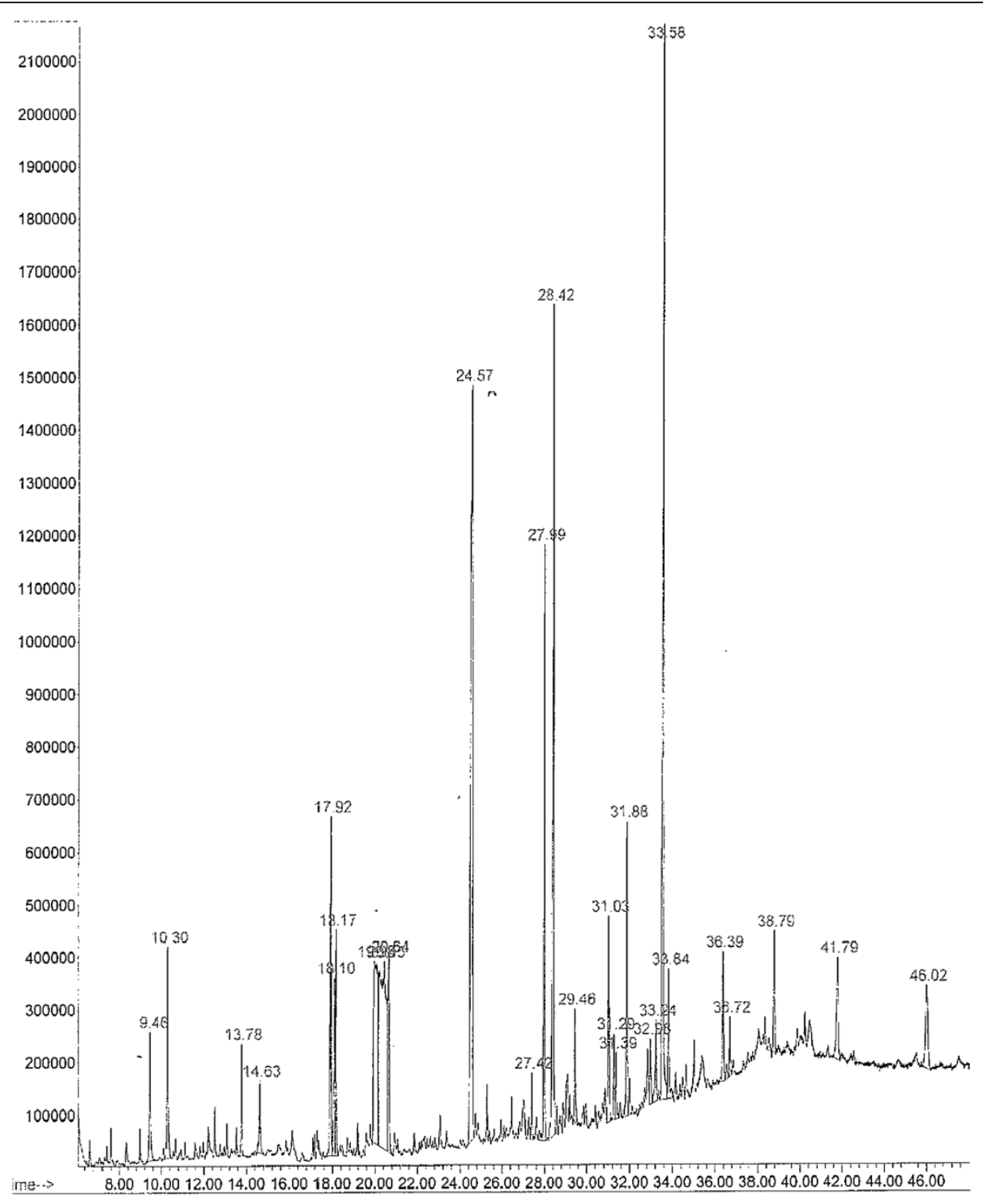

Figure 1 A typical Gas chromatography profile showing the chemical analysis of $M$. edule essential oil.

Majority of the volatile components analysed from plant essential oil largely belong to terpene. Terpenes are known to have strong biological activities and they are in involved in plant defences [24]. It has been well documented that the intake of terpenes can reduce accumulated toxins from the liver and kidneys in the body system [25]. In this study, Isoterpinolene (0.95\%), Nephthalene (3.93\%) and Bistrimethulesilyl N-acetyl (5.72\%), were identified as monoterpenes respectively. Oxygenated monoterpene were found to be the highest (36.61\%) constituents in the M. edule essential oil. Over the years, essential oil containing monoterpene hydrocarbons has offered a variety of healing properties, especially their ability to restore correct information in the DNA of a living cell and enhancement of other therapeutic components [26,27]. Isoterpinolene, one of the major monoterpenes observed in the study has been found capable of protecting human cells from free radical mediate oxidative stress [28]. It has been said that the oxygenated monoterpene compounds are more valuable than the monoterpene hydrocarbons due to their contribution to the fragrance of the essential oil [29].

Octadecanes $(1.76 \%), 1$-octadecane $(0.80 \%)$ and Nonadecane (1.02\%) were observed as sesquiterpene hydrocarbons in the M. edule essential oil. Essential oil containing sesquiterpenes have been used as therapeutic effect against inflammatory and allergic infections [30,31]. Research has found that people who consistently use sesquiterpenes essential oil have a higher level of resistance to illness than the average person [32]. Further indications revealed that if such individual eventually falls ill, he or she has a 
Table 2 Compounds obtained from GC/MS analysis of $M$. edule leaf part essential oil

\begin{tabular}{|c|c|c|c|c|}
\hline \multicolumn{5}{|c|}{ Percentage composition of $M$. edule essential oil analysed by GC/MS } \\
\hline PK/No & Compounds & Kovats index & Peak \% & Chemical formula \\
\hline & Monoterpenes & & 10.6 & \\
\hline 1 & Isoterpinolene & 1429 & 0.95 & $\mathrm{C}_{10} \mathrm{H}_{16}$ \\
\hline 2 & Nephthalene, 1,2-dihydro-2,5,8-tri & 1546 & 2.03 & $\mathrm{C}_{12} \mathrm{H}_{10}$ \\
\hline 3 & Nephthalene, 1,2-dihydro-2,5,8-tri & 1548 & 1.90 & $\mathrm{C}_{12} \mathrm{H}_{10}$ \\
\hline \multirow[t]{2}{*}{4} & Bistrimethylsilyl N-acetyl EICOSAS & 1978 & 5.72 & $\mathrm{C}_{15} \mathrm{H}_{33} \mathrm{NO}_{5} \mathrm{Si}_{3}$ \\
\hline & Oxygenated monoterpenes & & 36.61 & \\
\hline 5 & Mercaptoacetic acid, bis (trismethylsilyl) & 3740 & 2.07 & $\mathrm{C}_{8} \mathrm{H}_{20} \mathrm{O}_{2} \mathrm{SSi}_{2}$ \\
\hline 6 & Eicosamethylcyclodecasiloxane & 1936 & 2.58 & $\mathrm{C}_{8} \mathrm{H}_{24} \mathrm{O}_{4} \mathrm{Si}_{4}$ \\
\hline 7 & N-Octanol & 1297 & 1.59 & $\mathrm{C}_{8} \mathrm{H}_{18} \mathrm{O}$ \\
\hline 8 & Nonylaldehyde & 1345 & 2.29 & $\mathrm{C}_{9} \mathrm{H}_{18} \mathrm{O}$ \\
\hline 9 & Trans- $\beta$-demascenone & 1538 & 3.42 & $\mathrm{C}_{13} \mathrm{H}_{18} \mathrm{O}$ \\
\hline 10 & Trans-2-tridecenal & 1406 & 0.85 & $\mathrm{C}_{13} \mathrm{H}_{24} \mathrm{O}$ \\
\hline 11 & Tetradecamethylcycloheptasiloxane & 1627 & 7.39 & $\mathrm{C}_{14} \mathrm{H}_{42} \mathrm{O}_{7} \mathrm{Si}_{7}$ \\
\hline 12 & Tetradecamethylcycloheptasiloxane & 1646 & 13.57 & $\mathrm{C}_{14} \mathrm{H}_{42} \mathrm{O}_{7} \mathrm{Si}_{7}$ \\
\hline \multirow[t]{2}{*}{13} & Tetradecamethylcycloheptasiloxane & 1654 & 2.85 & $\mathrm{C}_{14} \mathrm{H}_{42} \mathrm{O}_{7} \mathrm{Si}_{7}$ \\
\hline & Sesquiterpenes & & 3.58 & \\
\hline 14 & Octadecane & 1991 & 0.64 & $\mathrm{C}_{18} \mathrm{H}_{38}$ \\
\hline 15 & Octadecane & 2092 & 1.12 & $\mathrm{C}_{18} \mathrm{H}_{38}$ \\
\hline 16 & 1-octadecene & 2266 & 0.80 & $\mathrm{C}_{18} \mathrm{H}_{36}$ \\
\hline \multirow[t]{2}{*}{17} & Nonadecane & 2284 & 1.02 & $\mathrm{C}_{18} \mathrm{H}_{40}$ \\
\hline & Oxygenated sesquiterpene & & 9.28 & \\
\hline \multirow[t]{2}{*}{18} & 2-pentadecanone,6,10,14-trimethyl & 2014 & 9.28 & $\mathrm{C}_{18} \mathrm{H}_{36} \mathrm{O}$ \\
\hline & Diterpenes & & 1.43 & \\
\hline 19 & Eicosane & 2215 & 0.65 & $\mathrm{C}_{20} \mathrm{H}_{42}$ \\
\hline \multirow[t]{2}{*}{20} & Eicosane & 2439 & 0.78 & $\mathrm{C}_{20} \mathrm{H}_{42}$ \\
\hline & Oxygenated diterpenes & & 19.24 & \\
\hline 21 & Phytol (2-Hexadecen-1-o1, 3,7,11,15-tetramethyl) & 2289 & 12.41 & $\mathrm{C}_{20} \mathrm{H}_{40} \mathrm{O}$ \\
\hline 22 & $\begin{array}{l}\text { Trisiloxane,1,1,1,5,5,5-hexamethyl-3-[(trimethylsilyl)oxy] } \\
\text { (Tetracosamethylcyclododecasiloxane) }\end{array}$ & 2302 & 1.64 & $\mathrm{C}_{24} \mathrm{H}_{72} \mathrm{O}_{12} \mathrm{Sil}_{2}$ \\
\hline 23 & $\begin{array}{l}\text { Tetrasiloxane, 1,1,1,5,7,7,7-heptamethyl-3, bis[(trimethylsilyl)oxy] } \\
\text { (Tetracosamethylcyclododecasiloxane) }\end{array}$ & 2420 & 1.66 & $2 \mathrm{C}_{24} \mathrm{H}_{72} \mathrm{O}_{12} \mathrm{Sil}_{2}$ \\
\hline 24 & $\begin{array}{l}\text { 3-Isopropoxy-1,1,1,7,7,7-hexamethyl-3,5,5-tri(trismethylsiloxy) } \\
\text { tetrasiloxane (Tetracosamethylcyclododecasiloxane) }\end{array}$ & 2538 & 1.69 & $2 \mathrm{C}_{24} \mathrm{H}_{72} \mathrm{O}_{12} \mathrm{Si}_{2}$ \\
\hline \multirow[t]{2}{*}{25} & $\begin{array}{l}\text { Tetrasiloxane-1,1,1,5,7,7,7-heptamethyl-3,3 bis[(trismethylsilyl)oxy)] } \\
\text { (Tetracosamethylcyclododecasiloxane) }\end{array}$ & 2680 & 1.84 & $2 \mathrm{C}_{24} \mathrm{H}_{72} \mathrm{O}_{12} \mathrm{Sil}_{2}$ \\
\hline & Fatty acids & & 19.25 & \\
\hline 26 & $\begin{array}{l}\text { Benzoic acid, 2,5-bis (trimethylsiloxy-,trimethylsilyl ester } \\
\text { (Tetracosamethylcyclododecasiloxane) }\end{array}$ & 1841 & 15.68 & $\mathrm{C}_{16} \mathrm{H}_{30} \mathrm{O}_{4} \mathrm{Si}_{3}$ \\
\hline 27 & Hexadecanoic acid, ethyl ester & 2183 & 0.89 & $\mathrm{C}_{18} \mathrm{H}_{36} \mathrm{O}_{2}$ \\
\hline \multirow[t]{2}{*}{28} & Hexadecanoic acid, 1-methylethyle ester & 2215 & 2.68 & $\mathrm{C}_{19} \mathrm{H}_{38} \mathrm{O}_{2}$ \\
\hline & Total compounds (\%) & & 99.99 & \\
\hline
\end{tabular}

Bold data $(10.6 ; 36.61 ; 3.58 ; 9.28 ; 1.43 ; 19.24 ; 19.25 ; 99.99)$ represents the percentage peak area values calculated for each terpenes and fatty acids hydrocarbon. 
tendency of recovering $60-70 \%$ faster than those who do not use essential oils [32,33].

Two Eicosane with a total area peaks of $1.43 \%$ were the major concentrated diterpenes detected from the M. edule essential oil. Oxygenated diterpene constituents accounted the third most concentrated hydrocarbons found in leaves, with a total essential oil content of $19.24 \%$. Of these, Phytol content gave the highest amount with area peak of $12.41 \%$, followed by all the Tetra-decamethylcycloheptasiloxanes, having area peak of $6.83 \%$. Total amount of fatty acids and their methyl esters content present in the essential oil extract were found to be $19.25 \%$. From Table 2 it is clear that benzoic acid represent the highest amount of $15.68 \%$ fatty acids of the essential oil.

Several bioactive compounds have been isolated from M. edule, such as phenolics, flavonoids, proanthocyanidins, alkaloids, saponins, tannin, rutin, cactichin, ferulic acid hyperoside, oleanolic acid, catechin and epicatechin [34-36]. Unfortunately, there is no available information on the profile chemical constituents from $M$. edule leaf essential oil. The different phytochemical constituents of monoterpene, sesquiterpenes, diterpenes and fatty acid esters have been reported to have antioxidant, antimicrobial, immune-modulating activities [37-39].

Microbiological screening of essential oil from many plants (Pimpinella anisum L. (anised), Syzygium aromaticum L. (clove), Cuminum cyminum L. (cumin), Allium sativum L. (garlic), Laurus nobilis L. (laurel), Citrus sinensis (L.) Osbeck (orange sweet), and Origanum vulgare L. (oregano), Tulbaghia violacea Harv L.F and Eucalyptus grandis W.Hill ex Maiden) have earlier been studied to have high antibacterial, antifungal, antiviral, antiparasitic and antidermatophytic properties [40-42]. From the antifungal results presented in Table 3 , the MIC of the essential oil effectively inhibited the growth of the organisms when compared to nystatin and amphotericin B used as control. The extent of inhibition on the fungal growth is dependent on the concentration used. Candida albican and C. krusei which are the most dangerous organisms in human system had the most sensitive treatment of 0.02 and $0.04 \mathrm{mg} / \mathrm{ml}$ activity.

Table 3 Minimum inhibitory concentration (MIC) of the extracts against the five fungal

\begin{tabular}{lccc}
\hline \multicolumn{3}{c}{ Minimum inhibitory concentration } \\
\hline Test organisms & $\begin{array}{c}\text { Essential oil } \\
(\mathbf{m g} / \mathbf{m l})\end{array}$ & $\begin{array}{c}\text { Nystatin } \\
(\mathbf{m g} / \mathbf{m l})\end{array}$ & $\begin{array}{c}\text { Amphotericin B } \\
(\mathbf{m g} / \mathbf{m l})\end{array}$ \\
\hline C. albican & $0.02^{-}$ & $0.02^{-}$ & 0.02 \\
C. krusei & $0.04^{\mathrm{a}}$ & $0.02^{\mathrm{b}}$ & $0.009^{\mathrm{c}}$ \\
C. rugosa & $0.08^{\mathrm{a}}$ & $0.02^{\mathrm{b}}$ & $0.009^{\mathrm{c}}$ \\
C. glabrata & $0.31^{\mathrm{a}}$ & $0.04^{\mathrm{b}}$ & $0.02^{\mathrm{b}}$ \\
C. neoformans & $0.08^{\mathrm{a}}$ & $0.009^{\mathrm{b}}$ & $0.02^{\mathrm{c}}$ \\
\hline
\end{tabular}

${ }^{\mathrm{abc}}$ Values within rows are significantly different $(p>0.05)$. The minus sign $(-)$ indicate negative result.
These findings agree with studies done on the Candida strain isolated from infants and standard strains [43]. Both strains were greatly inhibited by $80.95 \%$ and $14.23 \%$ essential oil of thyme, pennyroyal and lemon [43].

Minimum inhibitory activity of the essential oil against C. rugosa and C. neoformans $(0.08 \mathrm{mg} / \mathrm{ml})$ was significantly different from that of C. glabrata at $0.31 \mathrm{mg} / \mathrm{ml}$. Antifungal activity of Lavandula viridis L. essential oil against Cryptococcus neoformans was $0.64 \mu \mathrm{l} / \mathrm{ml}$, which is significantly higher than our result [44]. Other observations from Saeid and Seddighe [43], reported 2.3\% activity of essential oil against C. glabrata.

\section{Conclusion}

Conclusively, the results obtained from the GC-MS resulted in the identification of 28 hydrocarbons of the total essential oil. The phytoconstituent present in the essential oil are in the family of monoterpenes, sesquiterpenes, diterpenes, and fatty acids esters. Oxygenated monoterpenes occupies the major constituents of the oil, followed by fatty acids and oxygenated diterpenes. The therapeutic potency of $M$. edule used as traditional medicine thus contains properties that inhibit the growth of fungi activity. The growth of Candida albican and $C$. krusei which are the most common agent in candiadiasis patients were greatly reduced by $M$. edule essential oil. Mesembryanthemum edule match a candidate species for future studies on novel and alternative remedy for the treatment of microorganism infections. However, further studies will be carried out to isolate and identify the active compounds, and to determine their exact mechanism of action.

\section{Abbreviations}

HIV: Human immunodeficiency virus; AIDS: Acquired immunodeficiency syndrome; M. edule: Mesembryanthemum edule; UANOVA: Analysis of variance; MSD: Mass Selective Detector; GC-MS: Gas chromatography-mass spectrometry; ATCC: America type culture collection; MIC: Minimum inhibitory concentration.

\section{Competing interests}

The authors declare that they have no competing interests.

\section{Authors' contributions}

BEO was responsible for the collection of plant materials from the traditional healers, carried out $90 \%$ of the experiments, and drafted the manuscript. GB edited the manuscript. AJA participated in the GC-MS analysis, supervised in the laboratory assay and made substantial contribution to revise the manuscript critically. All authors read and approved the final manuscript.

\section{Acknowledgement}

This work was supported by the National Research Foundation of South Africa, University of Fort Hare.

\section{Author details}

'Department of Biochemistry and Microbiology, University of Fort Hare, Private Bag X1314, Alice 5700, South Africa. ${ }^{2}$ Department of Botany, University of Fort Hare, Private Bag X1314, Alice 5700, South Africa. 


\section{References}

1. Joint United Nations programme on HIV/AIDS UNAIDS: AIDS epidemic update. UNAIDS/09.36E/JC1700. 2009.

2. Wilfred $\mathrm{MO}$, Donald SG, Roland NN: The effect of the acetone extracts of arctotis arctotoides (asteraceae) on the growth and ultrastructure of some opportunistic fungi associated with HIV/AIDS. Int J Mol Sci 2011 12:9226-9235

3. Suzanne MN, Alexander DJ: Genetic of candida albicans, a diploid human fungal pathogen. Ann Rev Gene 2007, 41:193-211.

4. Majid Z, Ali Z: Mahmoudabadi. Invasive candidiasis; a review article. Jundishapur J Microbiol 2009, 2:1-61.

5. David LG, Hnin Khine MD, Jacob A, Dania JL, Liise-anne P, Ramata N: Serologic evidence for cryptococcus neoformans infection in early childhood. Paediatrics 2011, 107:5-66.

6. Behera B, Singh Rl, Xess I, Mathur P, Hasan F, Misra MC: Candida rugosa: a possible emerging cause of candidaemia in trauma patients. $J$ Infect Res 2010, 38:387-393.

7. Stein AC, Alvarez SS, Avancini C, Zacchino S, von Poser G: Antifungal activity of some coumarins obtained from species of Pterocaulon (Asteraceae). J Ethnopharmacol 2006, 107:95-98.

8. Vijay KJ, Hari PD, Xianghe Y: Comparison of antimicrobial activities of methanol extracts of Juglansregia against Staphylococcus aureus and Streptococcus mutans with ciprofloxacin. Annual Rev Food Sci Technol 2012, 3:381-403.

9. Sunita B, Mahendra R: Antifungal activity of essential oils from Indian medicinal plants against human pathogenic Aspergillus fumigatus and A. niger. World J Med Sci 2008, 3(2):81-88.

10. Siveen KS, Kuttan G: Immunomodulatory and antitumor activity of Aerva lanata ethanolic extract. Immunopharmacol Immunotoxicol 2010, 33(3):423-432.

11. Amini M, Safaie N, Salmani MJ, Shams-Bakhsh M: Antifungal activity of three medicinal plant essential oils against some phytopathogenic fungi. Trakia J Sci 2012, 10:1-8.

12. Beauty EO, Graeme B, Anthony JA: Antioxidant and phytochemical properties of Carpobrotus edulis (L.) bolus leaf used for the management of common infections in HIV/AIDS patients in Eastern Cape Province. BMC Com Alt Med 2012, 12: doi:10.1186/1472-6882-12-215.

13. Jin-Hui $L$, Jing $L$, Hong Z: Functional recovery after scutellarin treatment in transient cerebral ischemic rats: A pilot study with F-Fluorodeoxyglucose microPET. Evi Based Com Alt med 2013, 507091: doi./10.1155/2013/507091

14. Buwa LV, Afolayan AJ: Antimicrobial activity of some medicinal plants used for the treatment of tuberculosis in the Eastern Cape Province, South Africa. Afr J Biotechnol 2009, 8:6683-6687.

15. Sirirat S, Wimolpun R, Sanit S: Antifungal activity of essential oils derived from some medicinal plants against grey mould (boyrytis cinerea). Asian $J$ Food Ag Ind 2009, 36:229-233.

16. Nicholas AB, Stefan R, Nicole MP: Essential oils and future antibiotics: New weapons against emerging superbugs. J Anc Dis Prev Rem 2013, 1:2. doi.10.4172/2329-8731

17. Panahi Y, Akhavan A, Sahebkar A, Hosseini SM, Taghizadeh M, Akhari H, Sharif MR, Imani S: Investigation of the effectiveness of Syzygium aromaticum. Lavandula angustifolia and Geranium robertianum essential oils in the treatment of acute external otistis: A comparative trial with ciprofloxacin. J. Microbiol Immunol Infect 2012, 12:1182-1648.

18. Omoruyi BE, Bradley G, Afolayan AJ: Ethnomedicinal survey of medicinal plants used for the management of HIV/AIDS infection among local communities of Nkonkobe Municipality, Eastern Cape, South Africa. J Med Plants Res 2012, 6:3603-3608.

19. Tina M, Mia BK, Line M, Jesper BN, Sven E, Lisbeth EK: Placental passage of benzoic acid, caffeine, and glyphosate in an Ex vivo human perfusion system. J Toxicol Environ Health 2008, 71:984-991.

20. Ann-marie T, Denise DM: Caching as a behavioural mechanism to reduce toxin intake. J Mammal 2009, 90(4):803-810.

21. Valerie EM, Hector DG, Tami SM, Joseph MT, John TJ: Safe human exposure limits for airborne linear siloxanes during spaceflight. Inhal Toxicol 2013, 25(13):735-746.

22. Environment Canada and health Canada: Proposed risk management approach for cyclotetrasiloxane, cotamethyl-(D4) and cyclopentasiloxane, decemethyl-(D5). 2009, 541:02-06. http://www.ec.gc.ca/substances/ese/ eng/challenge/batch2/batch2.

23. Bogen KT, Benson JM, Yost GS, Morris JB, Dahl AR, Clewell HJ, Krishnan K, Omiecinski CJ: Nephthalene metabolism in relation to target tissue anatomy, physiology, cytotoxicity and tumorigenic mechanism of action. Reg Toxicol Pharmacol 2008, 51:27-36.

24. Michael R, Daniel M, Makihiko I, Moshe I: Gall volatiles defend aphids against a browsing mammal. BMC Evol Biol 2013, 13:193. doi:10.1186/1471-2148.

25. Martins MR, Tinoco MT, Alimeida ASI, Cruz-Morais J: Chemical composition, antioxidant and antimicrobial properties of three essential oils from Portuguese Flora. J Pharmacog 2012, 3:39-44.

26. Kamal GM, Anwar F, Hussain Al, Sarri N, Ashraf MY: Yield and chemical composition of Citrus essential oils as affected bydrying pretreatment of peels. Int J Food Res 2011, 18:1275-1282.

27. Santhi S, Sumathi R, Rajeshkannan C, Manivachakam P, Murugesan S: Profiling metabolites in different day cultures of a root endophyte, Frankia Brunchorst from Casuarina equisetifolia L. using GC-MS-MS. European J. Exp Bio/ 2012, 2:539-542

28. Carson CF, Hammer KA, Riley TV: Melaleuca alternifolia (Tea Tree) Oil: a Review of antimicrobial and other medicinal properties. Clini Microbiol Rev 2006, 19:50-62.

29. Xinxin Cl, Xiao C, Miaomiao W, Xiaofeng Y, Qinren C, Xuming D: Different effects of farrerol on an OVA-Induced allergic asthma and LPS-induced acute lung Injury. J Pone 2012, 7:4-34634.

30. Enzo AP: Traditional medicinal plant extracts and natural products with activity against oral bacteria: Potential application in the prevention and treatment of oral diseases. Evidence Based Com Alt Med 2011, 680354: http://dx.doi.org/10.1093/ecam/nep064.

31. Akram A, Urgen R, Schnitzler P: Screening for antiviral activities of isolated compounds from essential oils. Evidence Based Com Alt Med 2011, 253643: doi:10.1093/ecam/nep187.

32. Martins A, Vasas A, Schelz Z, Viveiros M, Molnar J, Hohmann J: Constituents of Carpobrotus edulis inhibit P-glycoprotein of Mdr1-transfected mouse lymphoma cells. Anticancer Res 2010, 30:829-835.

33. Dalia: Insecticidal and antifeedant activities and chemical composition of Casimiroa edulis La Llave \& Lex (Rutaceae) leaf extract and its fractions against Spodoptera Littoralis Larvae AB. Austr J Basic Appli Sci 2011, 5:693-703.

34. Falleh H, Ksouri R, Medini F, Guyot S, Abdelly C, Magne C: Antioxidant activity and phenolic composition of the medicinal and edible halophyte Mesembryanthemum edule L. Ind Crops Prod 2011, 34(1):1066-1071.

35. Falleh H, Ksouri R, Boulaaba M, Guyot S, Abdelly C, Magne C: Phenolic nature, occurrence and polymerization degree as marker of environmental adaptation in the edible halophyte Mesembryanthemum edule. South Afr J Bot 2012, 79:117-124.

36. Hanen F, Najla T, Michele B, Gaetan L, Chedly A, Christian M: Polypenolic content and biological activities of Mesembryanthemum edule organs after fractionation. Ind Crops Prod 2013, 42:145-152.

37. Chokoe PK, Masoko P, Mokgotho MP, Howard RL, Mampuru LJ: Does seasonal variation influence the phytochemical and antibacterial properties of Carpobrotus edulis? Afr J Biotechnol 2008, 7:4164-4171.

38. Bouftira I, Abdelly C, Sfar S: Antioxidant properties of Mesembryanthemum crystallinum and Carpobrotus edulis extracts. Asian J Chemo 2009, 21:549-559.

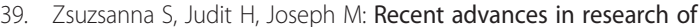
antimicrobial effects of essential oils and plant derived compounds on bacteria. Ethnomed Com Therapeutics 2010, 2010:179-201.

40. Ravi KU, Pratibha D, Shoeb A: Screening of antibacterial activity of six plant essential oil against pathogenic bacterial strains. Asian J Med SCi 2010, 2(3):152-158.

41. Oluwagbemiga SS, Adebola O, Albert KB, Andy RO: The essential oil of Eucalyptus grandis W. Hill ex maiden inhibits microbial growth by inducing membrane damage. Chin Med 2013, 4:7-14.

42. Nuzhat T, Vidyasagar GM: Antifungal investigations on plant essential oils. A review. Int J Pharm Pharm Sci 2013, 5:2-9.

43. Saeid MO, Seddighe E: Comparison of anti-Candida activity of thyme, pennyroyal, and lemon essential oil versus antifungal drugs against Candida species. Jundis J Microbiol 2009, 2(2):53-60.

44. Monica ZMJG, Carlos C, Jorge C, Luis V, Maria JS, Eugenia P, Ligia S: Chemical composition and antifungal activity of the essential oils of Lavandula viridis L'Her. J Med Microbiol 2011, 60:5612-5618.

doi:10.1186/1472-6882-14-168

Cite this article as: Omoruyi et al:: The inhibitory effect of

Mesembryanthemum edule (L.) bolus essential oil on some pathogenic fungal isolates. BMC Complementary and Alternative Medicine 2014 14:168. 